\title{
Advantages of multilocus sequence analysis for taxonomic studies: a case study using 10 housekeeping genes in the genus Ensifer (including former Sinorhizobium)
}

\author{
Miet Martens, Peter Dawyndt, Renata Coopman, Monique Gillis, \\ Paul De Vos and Anne Willems \\ Laboratorium voor Microbiologie (WE10), Universiteit Gent, K. L. Ledeganckstraat 35, \\ B-9000 Gent, Belgium
}

Correspondence Anne Willems

Anne.Willems@UGent.be

\begin{abstract}
There is a need for easy, practical, reliable and robust techniques for the identification and classification of bacterial isolates to the species level as alternatives to $16 \mathrm{~S}$ rRNA gene sequence analysis and DNA-DNA hybridization. Here, we demonstrate that multilocus sequence analysis (MLSA) of housekeeping genes is a valuable alternative technique. An MLSA study of 10 housekeeping genes (atpD, dnaK, gap, glnA, gltA, gyrB, pnp, recA, rpoB and thrC) was performed on 34 representatives of the genus Ensifer. Genetic analysis and comparison with $16 \mathrm{~S}$ and $23 \mathrm{~S}$ rRNA gene sequences demonstrated clear species boundaries and a higher discrimination potential for all housekeeping genes. Comparison of housekeeping gene sequence data with DNA-DNA reassociation data revealed good correlation at the intraspecies level, but indicated that housekeeping gene sequencing is superior to DNA-DNA hybridization for the assessment of genetic relatedness between Ensifer species. Our MLSA data, confirmed by DNA-DNA hybridizations, support the suggestion that Ensifer xinjiangensis is a later heterotypic synonym of Ensifer fredii.
\end{abstract}

\section{INTRODUCTION}

Nowadays, bacterial classification involves techniques to determine both phenotypic and genotypic characteristics. Of the genotypic methods, $16 \mathrm{~S}$ rRNA gene sequencing and genomic DNA-DNA reassociation serve as 'gold standards' for bacterial species determination (Stackebrandt \& Goebel, 1994). DNA-DNA hybridization involves a pairwise comparison of two entire genomes and reflects the overall sequence similarity between them. Currently, a species is defined as a set of strains with approximately $70 \%$ or greater DNA-DNA relatedness and with $5{ }^{\circ} \mathrm{C}$ or less $\Delta T_{\mathrm{m}}$. Phenotypic characteristics should be in agreement with this definition (Stackebrandt et al., 2002; Wayne et al., 1987). However, DNA-DNA hybridization is a technically challenging, labour-intensive and time-consuming method.

Abbreviations: ANI, average nucleotide identity; BT, bootstrap; ILD, incongruence-length difference; ML, maximum-likelihood; MLSA, multilocus sequence analysis; MP, maximum-parsimony; $\mathrm{NJ}$, neighbourjoining.

The GenBank/EMBL/DDBJ accession numbers of newly reported sequences are provided in Table 1.

Details of primers and PCR cycling conditions, scatter plots of genetic similarity, various parameters for some of the sequences analysed and results of ILD tests are available as supplementary material with the online version of this paper.
Also, it is not possible to establish a central database, mainly because the technique provides a non-cumulative, relative DNA relatedness value, but also because of technical nonuniformity and variability between different laboratories and methodologies (for a recent review of the different methods of DNA-DNA hybridization, see Rosselló-Mora, 2006). Moreover, the technique has the drawback that hybridization values of $50 \%$ or less are less informative and therefore DNA-DNA hybridizations are not suitable for the estimation of genetic distances between distantly related species (Owen \& Pitcher, 1983).

Together with DNA-DNA hybridization, sequence analysis of the 16S rRNA gene is also standard practice in bacterial taxonomy. In contrast to the former technique, 16S rRNA gene sequence analysis has demonstrated high resolving power for measuring the degree of relatedness between organisms above the species level (Stackebrandt \& Goebel, 1994). It has been observed that organisms with total genomic relatedness above $70 \%$ (assessed by DNA-DNA hybridization) share more than $97 \%$ 16S rRNA gene sequence similarity (Stackebrandt \& Goebel, 1994). In contrast to DNA-DNA hybridization, however, 16S rRNA gene sequence analysis often lacks resolving power at and below the species level; several studies have reported bacteria that represent different species with identical or 
nearly identical $16 \mathrm{~S}$ rRNA gene sequences (Amann et al., 1992; Fox et al., 1992; Jaspers \& Overmann, 2004; Sullivan et al., 1996). Therefore, an absolute minimal 16S rRNA gene sequence similarity value for the delineation of species cannot be set (Goodfellow et al., 1997). A further potential problem for identification purposes is 16S rRNA gene sequence heterogeneity due to the occurrence of multiple rrn operons within single genomes (Acinas et al., 2004).

As more whole-genome sequences become available, various new opportunities to study the genetic relatedness of bacterial strains may be exploited. Coenye et al. (2005) described several novel approaches, e.g. comparison of gene order, gene content, nucleotide composition and codon usage, to assess bacterial relationships based on whole-genome sequences. Konstantinidis \& Tiedje (2005) defined the average nucleotide identity (ANI) as the percentage of the total genomic sequence shared between two strains. The ANI was proven to be a robust and sensitive tool for measurement of the genetic relatedness between allied bacterial strains (from strain to genus level and possibly family level) (Konstantinidis \& Tiedje, 2005; Konstantinidis et al., 2006). Notwithstanding the fact that whole-genome sequencing projects are delivering new sequences at a rapidly increasing pace, the limited availability of whole-genome sequences of related strains and taxonomic reference strains currently restricts the use of whole-genomebased approaches for broad-spectrum identification and phylogenetic purposes. Therefore, reliable alternatives, which do not require full genome sequences, for the assessment of bacterial relationships are needed. For example, Cho \& Tiedje (2001) developed a method based on random genome fragments and DNA microarray technology that can be applied to the identification of bacteria as well as the determination of the genetic distance between bacteria. This alternative DNA-DNA hybridization technique provides species- to strain-level resolution and avoids laborious cross-hybridizations.

Recently, the analysis of multiple protein-encoding housekeeping genes has become a widely applied tool for the investigation of taxonomic relationships (Adekambi \& Drancourt, 2004; Christensen et al., 2004; Holmes et al., 2004; Naser et al., 2005; Thompson et al., 2005; Wertz et al., 2003). The use of information from the comparison and combination of multiple genes can give a global and reliable overview of interorganismal relationships. The ad hoc committee for re-evaluation of the species definition regarded the sequencing of a minimum of five well-chosen housekeeping genes, universally distributed, present as single copies and located at distinct chromosomal loci, as a method of great promise for prokaryotic systematics (Stackebrandt et al., 2002). In comparison with $16 \mathrm{~S}$ rRNA genes, the higher degree of sequence divergence of housekeeping genes is superior for identification purposes, since the more-conserved rRNA gene sequences do not always allow species discrimination. Zeigler (2003) stated that a small number of carefully selected gene sequences could equal, or perhaps even surpass, the precision of
DNA-DNA hybridization for quantification of genome relatedness. In contrast to DNA-DNA hybridization and $16 \mathrm{~S}$ rRNA gene sequence analysis, multilocus sequence analysis (MLSA) is capable of yielding sequence clusters at a wide range of taxonomic levels, from intraspecific through the species level to clusters at higher levels (Gevers et al., 2005). However, in order to validate the MLSA approach, the ad hoc committee for re-evaluation of the species definition called for comparative studies with organisms for which DNA-DNA reassociation data are available and the intraspecific diversity has been evaluated by DNA profiling methods (Stackebrandt et al., 2002).

In a previous study, we evaluated five housekeeping genes for their use as taxonomic and phylogenetic markers in the genus Ensifer (Martens et al., 2007). The genus Ensifer, comprising the former Sinorhizobium species and Ensifer adhaerens (Young, 2003), belongs to the Alphaproteobacteria and contains bacteria capable of nitrogen fixation in symbiosis with leguminous plants. Since Ensifer and Sinorhizobium represent synonymous genera (Martens et al., 2007; Willems et al., 2003; Young, 2003) and, as the oldest genus name, Ensifer has priority, we apply the Ensifer nomenclature according to Young (2003) for most Sinorhizobium species. A Request for an Opinion to grant priority to Sinorhizobium (Willems et al., 2003) was denied by the Judicial Commission. Transfer of Sinorhizobium morelense to the genus Ensifer is not yet possible since this species is the subject of a pending Request for an Opinion (Euzéby \& Tindall, 2004) and we therefore refer to this species here as 'S. morelense'. Also, Sinorhizobium americanum has not been transferred to the genus Ensifer because this species was not described at the time of the request of Young (2003). Our data confirmed that MLSA of housekeeping genes is superior to 16S rRNA gene sequence analysis for Ensifer species discrimination (Martens et al., 2007). Here, five additional housekeeping genes, $r p o B$ (RNA polymerase, beta subunit), atpD (ATP synthase F1, beta subunit), gap (glyceraldehyde-3-phosphate dehydrogenase), pnp (polyribonucleotide nucleotidyltransferase) and $\operatorname{gyrB}$ (DNA gyrase B subunit), as well as the $23 \mathrm{~S}$ rRNA gene, were examined. The phylogeny of the different genes was determined and results from the previous study were integrated in a large MLSA study. MLSA data were compared with DNA-DNA hybridization values and rRNA gene sequence data and the potential of MLSA for systematics and classification of strains was evaluated for the genus Ensifer.

\section{METHODS}

Strains and culture conditions. A total of 34 Ensifer strains were used in this study (Table 1): 27 strains representing all known former Sinorhizobium species (except for Ensifer kummerowiae, for which we could not obtain a bona fide strain) and seven strains representing the three different genomovars (A, B and C) of E. adhaerens. In addition, 14 rhizobial strains were included as reference strains. These additional strains represent the genera Bradyrhizobium, Allorhizobium, Rhizobium, Mesorhizobium and Agrobacterium. All 
Table 1. Strains used and EMBL/GenBank/DDBJ accession numbers

Accession numbers of new data are listed in bold.

\begin{tabular}{|c|c|c|c|c|c|c|c|c|}
\hline Strain & $\begin{array}{c}\text { Other } \\
\text { number }\end{array}$ & $\begin{array}{l}23 S \text { rRNA } \\
\text { gene }\end{array}$ & rpoB & $p n p$ & $\operatorname{atpD}$ & gap & gyrB & Source \\
\hline $\begin{array}{l}\text { Sinorhizobium } \\
\text { americanum } \text { LMG } \\
22684^{\mathrm{T}}\end{array}$ & $\begin{array}{l}\text { CFNEI } \\
156^{\mathrm{T}}\end{array}$ & AM418707 & AM295361 & AM295474 & AM418741 & AM295395 & AM418790 & $\begin{array}{l}\text { Acacia acatlensis, Sierra de Huautla, } \\
\text { Mexico }\end{array}$ \\
\hline \multicolumn{9}{|l|}{ Ensifer arboris } \\
\hline LMG $14919^{\mathrm{T}}$ & $\begin{array}{l}\text { HAMBI } \\
1552^{\mathrm{T}}\end{array}$ & AM418716 & AM295380 & AM295482 & AM418767 & AM295420 & AM418815 & Prosopis chilensis, Kosti, Sudan \\
\hline LMG 14917 & $\begin{array}{l}\text { HAMBI } \\
1396\end{array}$ & AM418739 & AM295381 & AM295483 & AM418776 & AM295429 & AM418824 & Prosopis chilensis, Kenya \\
\hline LMG 19223 & $\begin{array}{l}\text { HAMBI } \\
1704\end{array}$ & AM418738 & AM295379 & AM295481 & AM418757 & AM295410 & AM418805 & Acacia senegal, Khartoum, Sudan \\
\hline \multicolumn{9}{|l|}{ Ensifer fredii } \\
\hline LMG $6217^{\mathrm{T}}$ & USDA $205^{\mathrm{T}}$ & ${ }^{\mathrm{T}} \mathrm{AY} 244360$ & AM295358 & AM295458 & AM418761 & AM295414 & AM418809 & Glycine max, Honan, China \\
\hline \multicolumn{9}{|l|}{ Ensifer kostiensis } \\
\hline LMG $19227^{\mathrm{T}}$ & $\begin{array}{c}\text { HAMBI } \\
1489^{\mathrm{T}}\end{array}$ & AM418717 & AM295369 & AM295479 & AM418771 & AM295424 & AM418819 & Acacia senegal, Kosti, Sudan \\
\hline LMG 14911 & $\begin{array}{l}\text { HAMBI } \\
1502\end{array}$ & AM418736 & AM295370 & AM295480 & AM418774 & AM295427 & AM418822 & Acacia senegal, Tendelti, Sudan \\
\hline LMG 19225 & $\begin{array}{l}\text { HAMBI } \\
1484\end{array}$ & AM418734 & AM295368 & AM295478 & AM418770 & AM295423 & AM418818 & Prosopis chilensis, Kosti, Sudan \\
\hline \multicolumn{9}{|l|}{ Ensifer medicae } \\
\hline LMG $19920^{\mathrm{T}}$ & $\mathrm{R}-916$ & AM418714 & AM295387 & AM295484 & AM418754 & AM295407 & AM418802 & Medicago truncatula, Aude, France \\
\hline LMG 19921 & $\mathrm{R}-481$ & AM418741 & AM295386 & AM295486 & AM418778 & AM295431 & AM490194 & Medicago truncatula \\
\hline LMG 18864 & $\begin{array}{l}\text { HAMBI } \\
1809\end{array}$ & AM418733 & AM295385 & AM295485 & AM418769 & AM295422 & AM418817 & Medicago truncatula, Syria \\
\hline $\begin{array}{l}\text { Ensifer sp. LMG } \\
20571\end{array}$ & $\mathrm{R}-4955$ & AM418718 & AM295378 & AM295461 & AM418772 & AM295425 & AM418820 & Agricultural soil, Pittem, Belgium \\
\hline \multicolumn{9}{|l|}{ Ensifer saheli } \\
\hline LMG $7837^{\mathrm{T}}$ & ORS $609^{\mathrm{T}}$ & AY244368 & AM295362 & AM295475 & AM418756 & AM295409 & AM418804 & Sesbania cannabina, Dakar, Senegal \\
\hline LMG 11864 & ORS 600 & AM418740 & AM295365 & AM295477 & AM418777 & AM295430 & AM418825 & Sesbania pachycarpa, Senegal \\
\hline LMG 8310 & ORS 611 & AM418731 & AM295363 & AM295476 & AM418765 & AM295418 & AM418813 & Sesbania grandiflora, Dakar, Senegal \\
\hline \multicolumn{9}{|l|}{ Ensifer terangae } \\
\hline LMG $7834^{\mathrm{T}}$ & ORS $1009^{\mathrm{T}}$ & AY244369 & AM295366 & AM295469 & AM418764 & AM295417 & AM418812 & Acacia laeta, Dakar, Senegal \\
\hline LMG 11859 & ORS 52 & AM418732 & AM295367 & AM295470 & AM418766 & AM295419 & AM418814 & Sesbania rostrata, Senegal \\
\hline LMG 6464 & ORS 51 & AM418730 & AM295364 & AM295468 & AM418763 & AM295416 & AM418811 & Sesbania rostrata, Dakar, Senegal \\
\hline \multicolumn{9}{|c|}{ Ensifer xinjiangensis } \\
\hline LMG $17930^{\mathrm{T}}$ & $\begin{array}{l}\text { CCBAU } \\
110^{\mathrm{T}}\end{array}$ & AM418708 & AM295355 & AM295455 & AM418745 & AM295398 & AM418793 & Glycine max, Xinjiang, China \\
\hline R-16438 & $\begin{array}{c}\text { CCBAU } \\
83834\end{array}$ & AM418726 & AM295356 & AM295456 & AM418751 & AM295404 & AM418799 & Not known \\
\hline \multicolumn{9}{|l|}{$\begin{array}{l}\text { Ensifer adhaerens } \\
\text { gv. C }\end{array}$} \\
\hline LMG $20216^{\mathrm{T}}$ & $\begin{array}{l}\text { ATCC } \\
33212^{\mathrm{T}}\end{array}$ & AM418709 & AM295374 & AM295452 & AM418746 & AM295399 & AM418794 & Soil, central Pennsylvania, USA \\
\hline
\end{tabular}


Table 1. cont.

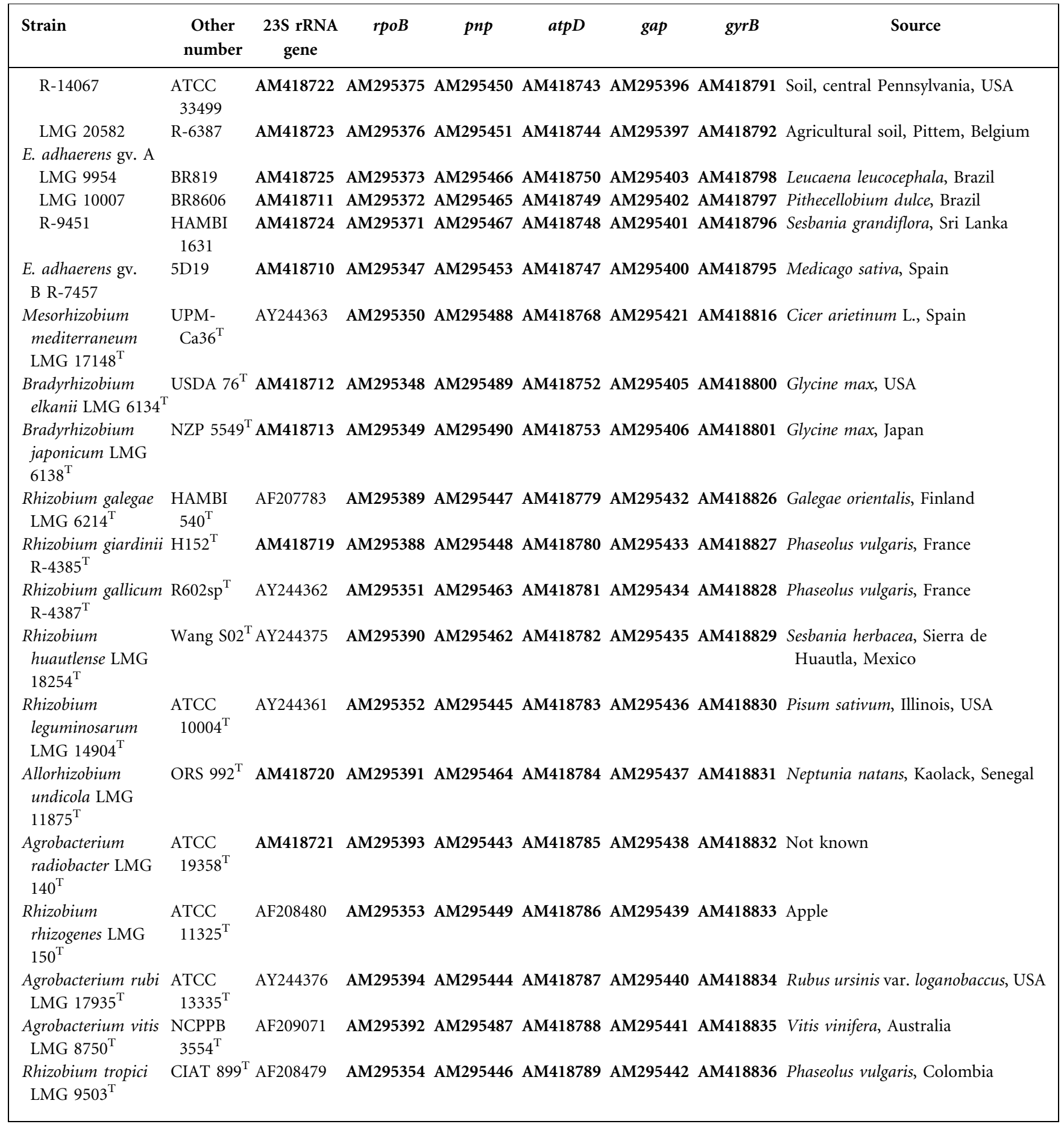

bacterial strains were grown on yeast extract mannitol agar (YMA) at $28{ }^{\circ} \mathrm{C}$.

DNA preparation. Bacterial DNA was prepared using the alkaline lysis method as described by Baele et al. (2000).

Primers for amplification and sequencing. The following genes were studied: $r p o B$ (RNA polymerase, beta subunit), atpD (ATP synthase F1, beta subunit), the $23 \mathrm{~S}$ rRNA gene, gap (glyceraldehyde-3-phosphate dehydrogenase), pnp (polyribonucleotide nucleotidyltransferase) and
gyrB (DNA gyrase B subunit). Primers for the amplification of the 23S rRNA gene were obtained from Van Camp et al. (1993). To design primers for PCR amplification and sequencing of the housekeeping genes, we used the corresponding sequences derived from the wholegenome sequences of related bacteria: Agrobacterium tumefaciens C58 (Goodner et al., 2001; Wood et al., 2001), Ensifer meliloti 1021 (Galibert et al., 2001), Mesorhizobium huakuii MAFF 303099 (Kaneko et al., 2000; Turner et al., 2002), Brucella melitensis $16 \mathrm{M}^{\mathrm{T}}$ (DelVecchio et al., 2002) and Bradyrhizobium japonicum USDA 110 (Kaneko et al., 2002). The gene sequences were compared using the BioNumerics 4.6 software 
package (Applied Maths) in order to identify conserved regions for the development of suitable primers. The primers used are listed in Supplementary Table S1 (available in IJSEM Online).

PCR amplification and sequencing of the genes. PCR amplification was performed as described previously (Martens et al., 2007). The cycling conditions are listed in Supplementary Table S1. The presence of PCR products and their concentration were verified by electrophoresis of $3 \mu \mathrm{l}$ product on a $1 \%$ agarose gel and staining with ethidium bromide. A molecular size marker (SmartladderEurogentec) was included to estimate the length of the amplification products.

The amplified products were purified using a Qiaquick PCR purification kit (Qiagen). The purified DNA was sequenced using the dideoxynucleotide chain-termination method with fluorescent ddNTPs (Applied Biosystems) on an ABI Prism 3100 capillary sequencer according to manufacturer's instructions (Applied Biosystems). Consensus sequences were constructed using the AutoAssembler software (Applied Biosystems). Accession numbers of new sequence data are listed in bold in Table 1 .

Sequence data analyses. The TaxonGap software tool (Naser et al., 2007) was applied to represent the resolution of the different genes within and between taxonomic units. For each gene and each species/ genomovar, the amount of heterogeneity (sequence divergence within a species/genomovar) and the amount of separability (smallest amount of sequence divergence observed between a particular species/ genomovar and the other species/genomovars; the species displaying the smallest amount of sequence divergence from the particular species is referred to as the closest neighbour taxon) were calculated. Distances used for the calculation of heterogeneity and separability values were determined using pairwise sequence alignments by the NeedlemanWunsch algorithm as implemented in BioNumerics 4.6.

Nucleotide sequence alignments were made using CLUSTAL_X (Thompson et al., 1997) and RevTrans 1.4 (Wernersson \& Pedersen, 2003), taking into account the corresponding amino acid alignments for protein-encoding genes. To assess the influence of noise due to saturation of the third codon position, we performed incongruence-length difference (ILD) tests (Farris et al., 1995) as implemented in PAUP* version 4.0b10 (Swofford, 2002), using the different codon positions as separate partitions in 1250 replications. The same set of strains was used for all genes and sequence data for Caulobacter crescentus CB15, extracted from the complete genome sequence (Nierman et al., 2001), were used as an outgroup. Neighbour-joining (NJ), maximum-parsimony (MP) and maximum-likelihood (ML) analyses were performed with PAUP* ${ }^{*}$ NJ analyses were performed using the Kimura-2 correction and 1000 bootstrap (BT) replications; MP analyses were performed using the heuristic search option. For ML analyses, the optimal models of nucleotide substitution were estimated using the program MODELTEST 3.7 (Posada \& Crandall, 1998) using both hierarchical likelihood ratio tests (hLRTs) and the Akaike information criterion (AIC) (Supplementary Table S2). When these options did not yield the same model, which was the case for the rpoB, gap, pnp and 23S rRNA genes, trees were constructed and compared using the different models. Since only negligible differences in tree topology and BT values were observed, only the trees constructed with the AIC model were used (Posada \& Buckley, 2004). The MP trees were used as starting trees for the heuristic search procedure. BT analyses were performed using 1000 replications of heuristic searches for MP and 100 replications for ML. The ILD test implemented in PAUP ${ }^{*}$ and using 1250 replicates was used to assess incongruence between datasets for the different genes.

DNA-DNA hybridization. DNA-DNA hybridizations were performed with Ensifer fredii strains LMG $6217^{\mathrm{T}}$ and LMG 8317 and
Ensifer xinjiangensis strains LMG $17930^{\mathrm{T}}$, R-16438 (=CCBAU 83834) and R-16439 (=CCBAU 83827). DNA was prepared as described by Willems et al. (2001) applying a slightly modified procedure of Marmur (1961). Hybridizations were carried out using a microplate method and biotinylated probe DNA (Ezaki et al., 1989). Hybridizations were performed at $45{ }^{\circ} \mathrm{C}$ in $2 \times$ SSC in the presence of $50 \%$ formamide (Willems et al., 2001).

Correlation of DNA-DNA hybridization values with MLSA data. Similarity plots (scatter plots) between DNA-DNA hybridization values and sequence similarity values were constructed in BioNumerics 4.6. Correlation between values was calculated using Pearson's product-moment correlation coefficient (Supplementary Fig. S1).

\section{RESULTS AND DISCUSSION}

In the present study, nucleotide sequences of the $r p o B$ (RNA polymerase, beta subunit), atpD (ATP synthase F1, beta subunit), gap (glyceraldehyde-3-phosphate dehydrogenase), $p n p$ (polyribonucleotide nucleotidyltransferase) and $\operatorname{gyrB}$ (DNA gyrase B subunit) housekeeping genes and the 23S rRNA gene were determined for 34 Ensifer strains and 14 other rhizobial strains (Table 1). The genes selected are widely distributed, unique within the genome, of adequate length to be phylogenetically informative, located separately on the main chromosome (as assessed from the E. meliloti complete genome) and have a relatively high degree of conservation (as established from the literature) (Zeigler, 2003). Except for pnp, the housekeeping genes analysed in this study were reported previously as good taxonomic markers (Mollet et al., 1997; Rönner et al., 1991; Wertz et al., 2003; Yamamoto \& Harayama, 1995). Amplification was successful for all strains. The length of the amplified fragments was $474-489$ bp for atpD, 798804 bp for gap, 666-699 bp for $g y r B, 954$ bp for $r p o B$, $540 \mathrm{bp}$ for $p n p$ and 1884-1897 bp for the 23S rRNA gene. For Ensifer medicae LMG 19921, a highly divergent gyrB sequence (1169 bp; 57.7 and $59.2 \%$ sequence similarity with E. medicae strains LMG 19920 and LMG 18864, respectively) was obtained which severely complicated the alignment. Query of the translated amino acid sequence via BLAST (Altschul et al., 1997) against the NCBI bacterial database revealed $76 \%$ similarity ( $53 \%$ identity) with the GyrB sequence of an alphaproteobacterial Sphingopyxis alaskensis strain as the closest match. Horizontal transfer and subsequent recombination could be a possible explanation for this aberrant $g y r B$ sequence. Another aberrant result was found for the $23 \mathrm{~S}$ rRNA gene from Ensifer arboris LMG $14919^{\mathrm{T}}$, which contained a $98 \mathrm{bp}$ insert near the $5^{\prime}$ end (total sequence length $1983 \mathrm{bp}$ ). Previously, Selenska-Pobell \& Evguenieva-Hackenberg (1995) reported the presence of a highly variable $130 \mathrm{bp}$ insert near the $5^{\prime}$ end of the $23 \mathrm{~S}$ rRNA gene in some members of the Rhizobiaceae. However, the position and sequence of the insert were different from those of the 98 bp insert found in LMG $14919^{\mathrm{T}}$.

For analyses of the sequences, we also included the corresponding sequences retrieved from the complete 
genome sequences of Agrobacterium tumefaciens C58 (Goodner et al., 2001; Wood et al., 2001), Brucella melitensis $16 \mathrm{M}^{\mathrm{T}}$ (DelVecchio et al., 2002), Brucella suis $1330^{\mathrm{T}}$ (Paulsen et al., 2002), Caulobacter crescentus CB15 (Nierman et al., 2001), Ensifer meliloti 1021 (Galibert et al., 2001), Rhodopseudomonas palustris CGA009 (Larimer et al., 2004), Mesorhizobium huakuii MAFF 303099 (Kaneko et al., 2000; Turner et al., 2002) and Bradyrhizobium japonicum USDA 110 (Kaneko et al., 2002). The lengths of the alignments used for individual gene analyses are listed in Supplementary Table S2. The alignments for atpD, gap, gyrB and the $23 \mathrm{~S}$ rRNA gene contained gaps, whereas no gaps were present for $r p o B$ or $p n p$. For the $23 \mathrm{~S}$ rRNA gene, due to the intrinsically uncertain alignment because of low sequence similarity and length variations, a continuous region of 22 bases (positions 970-991 of the multiple alignment) was omitted from the analyses.

\section{Individual gene analyses}

The potential of the different genes to identify the Ensifer species/genomovars was assessed. Suitable molecular markers for identification purposes exhibit the smallest amount of heterogeneity within a species/genomovar and result in maximal separation between the different species/ genomovars. All three codon positions were included in the individual gene analyses since no significant codon saturation was observed for the different codon positions (data not shown). For the calculation of the heterogeneity and separability values, E. xinjiangensis (two strains) and $E$. fredii (four strains) were considered as synonymous species (see below) since their gene sequences were identical (23S rRNA gene, atpD, $p n p$ and $r p o B$ ) or very similar (98.4$100 \%$ for gap and $97.2-100 \%$ for gyrB) in all comparisons. However, a DNA-DNA hybridization value of $39 \%$ was reported (Peng et al., 2002) between the two type strains. We repeated these hybridizations and included two additional E. xinjiangensis strains, R-16438 and R-16439, and found hybridization values of $78-85 \%$. With a second E. fredii strain, LMG 8317, values were $74-89 \%$, thus establishing that Ensifer xinjiangensis is a later heterotypic synonym of Ensifer fredii. The close relationship and probable synonymy of E. xinjiangensis and $E$. fredii was reported previously based on sequence analyses of the $16 \mathrm{~S}$ rRNA gene (Tan et al., 1997), the internally transcribed spacer region (Kwon et al., 2005) and housekeeping genes (Martens et al., 2007).

Sequence data from this and our previous study (Martens et al., 2007) were combined, and the heterogeneity and separability values were calculated for the 10 housekeeping genes ( $a t p D, d n a K$, gap, glnA, gltA, gyrB, recA, rpoB, pnp, thrC) and the $16 \mathrm{~S}$ and $23 \mathrm{~S}$ rRNA genes using TaxonGap (Naser et al., 2007). Results are summarized in Fig. 1. For each Ensifer species (or genomovar), sequences of the same gene for the different strains included were highly similar and, as a consequence, heterogeneity values (indicated by the light-grey bars in Fig. 1) were low (sequence divergence ranged from $0-0.8 \%$ for atpD to $0-2.8 \%$ for $g y r B$; for the $16 \mathrm{~S}$ and $23 \mathrm{~S} \mathrm{rRNA}$ genes, values were respectively $0-0.4 \%$ and $0-0.8 \%)$. This is mainly due to genuine low intraspecies/intragenomovar sequence variability, but also partially to inclusion of relatively few strains (two to four) per species/genomovar. Ensifer species displaying some intraspecies heterogeneity are E. arboris, E. adhaerens gv. A and C, E. fredii, E. meliloti and Ensifer saheli. Sequence divergence between Ensifer species for the housekeeping genes was clearly higher, ranging from $3.1-12.5 \%$ for $g \ln A$ to $5.8-20.5 \%$ for $t h r C$, which is reflected in the high separability values (indicated by the dark-grey bars in Fig. 1). In contrast, for the $16 \mathrm{~S}$ and $23 \mathrm{~S}$ rRNA genes, sequence divergence between species was only $0.2-2.1 \%$ and $0.4-3.9 \%$, respectively. For each species/genomovar, there is a clear gap between the heterogeneity and separability values for each of the housekeeping genes. This implies that the Ensifer species and genomovars form distinct groups, well separated from each other, for all housekeeping gene sequences analysed. The housekeeping genes with the best capability to identify Ensifer strains, due to high separability and low heterogeneity values, are $g y r B$, $g l t A, r e c A$ and $t h r C$. The rRNA genes, however, exhibit no or very little separability between species. As a consequence, rRNA gene sequence analysis does not always allow species identification: for example, 16S rRNA gene sequencing does not allow discrimination of $E$. fredii (including E. xinjiangensis) and S. americanum and $23 S$ rRNA gene sequences can not separate Ensifer sp. LMG 20571 and ' $S$. morelense'. Although the 23S rRNA gene contains more phylogenetic information than the $16 \mathrm{~S}$ rRNA gene (Woese, 1987), housekeeping genes are more discriminatory and thus superior for the identification of strains from closely related lineages. The same conclusion could be drawn when determining the number of parsimony-informative sites to estimate of the amount of phylogenetic information contained in each gene (see Supplementary Table S2).

Initial NJ trees of the individual genes including all strains revealed a tight clustering of strains within each species/ genomovar (data not shown), in line with low heterogeneity values computed by TaxonGap (Fig. 1). Therefore, only the type strains (except for E. adhaerens, where the three genomovars were included) were selected for further individual gene analyses in order to reduce computing time. The ML trees constructed from the individual $a t p D$, gap, gyrB, $p n p, r p o B$ and $23 \mathrm{~S}$ rRNA gene alignments are shown in Fig. 2 (for the remaining gene trees, see Martens et al., 2007). Considerable variation in tree topology was observed for all of the separate genes. In the $r p o B$ and $g y r B$ analyses, the different Ensifer species formed a single and significant cluster (BT values of 81 and $89 \%$, respectively). A close phylogenetic relationship was observed between $E$. meliloti, E. medicae and E. arboris for these genes (see also closest-neighbour analysis in Fig. 1). For $r p o B$, a tight clustering was also demonstrated for the species $E$. fredii (and the synonymous species E. xinjiangensis) and $S$. 


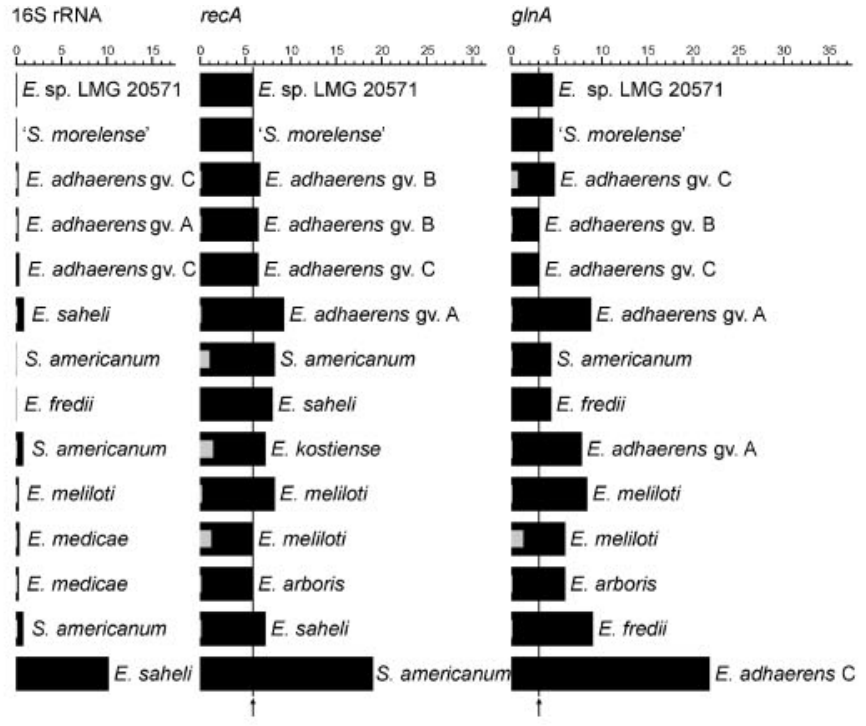

dnak thrC

gitt

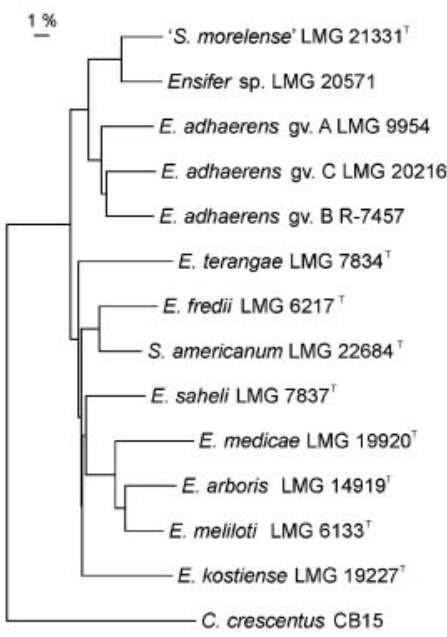

E. sp. LMG 20571
S. morelense'
E. adhaerens gv. B
E. adhaerens gv. B
E. adhaerens gv. A
E. americanum
E. fredii
E. fredii
E. meliloti
E. meliloti
E. arboris

\begin{tabular}{l} 
E. sp. LMG 20571 \\
S. morelense' \\
E. adhaerens gv. B \\
E. adhaerens gv. B \\
E. adhaerens gv. A \\
E. saheli \\
E. saheli \\
E. meliloti \\
E. arboris \\
E. meliloti \\
E. arboris \\
\hline E. saheli
\end{tabular}

E. adhaerens gv. B
E. adhererens gv. C
E. adhaerens gv. B
E. adhaerens gv. C
E. fredii
E. meliloti
E. arboris
E. meliloti
E. arboris
E. adhaerens gv. A

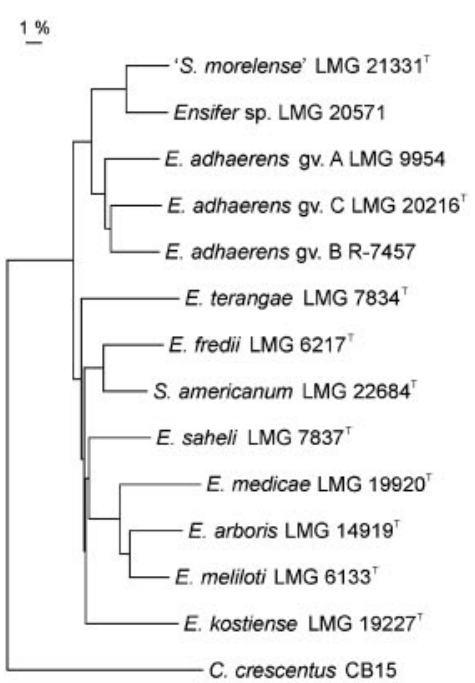

23S rRNA

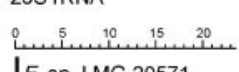

|E. sp. LMG 20571

|'S. morelense'

E. adhaerens gv. B

E. sp. LMG 20571

E. sp. LMG 20571

E. saheli

E. arboris

E. kostiense

E. kostiense

E. arboris

JE. medicae

IE. fredii

S. americanum

rpoB

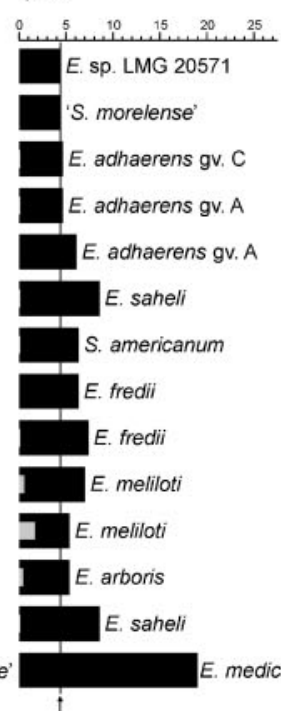

atpD gap

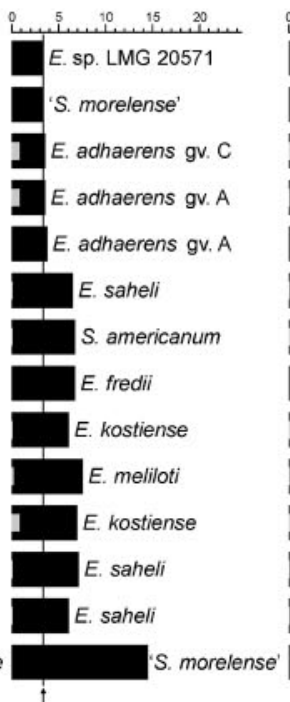

gap pnp

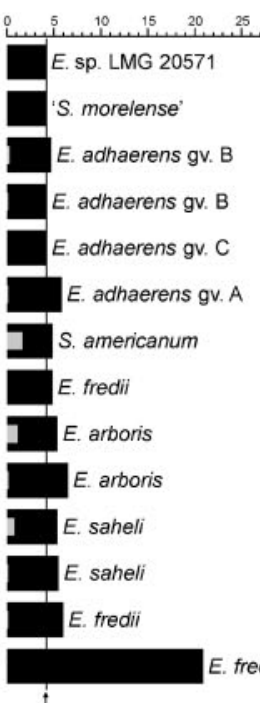

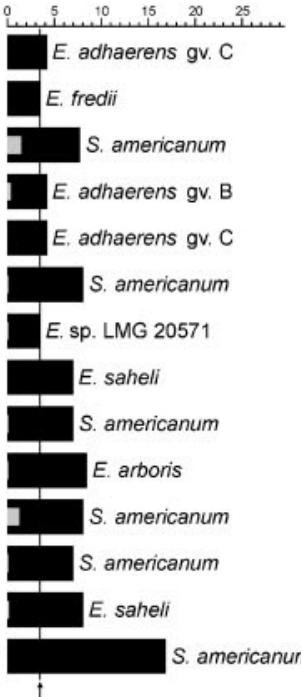

gyrB

S. morelense'

Fig. 1. Matrix of heterogeneity (light-grey bars) and separability (dark-grey bars) values with the different species/genomovars as matrix rows and the different genes as matrix columns, as calculated by TaxonGap. Species/genomovars were ordered according to their phylogenetic position in an ML tree calculated from the concatenated sequences of their type strains (when available) or another representative strain (see tree on the left). For each species/ genomovar and each gene, the closest neighbour (i.e. the taxon with the smallest separability for this species and this gene) is listed to the right of the darkgrey bar. For each gene, the vertical line denotes the smallest separability recorded. Bars in the ML trees, $1 \%$ estimated substitutions. 
235 rRNA gene

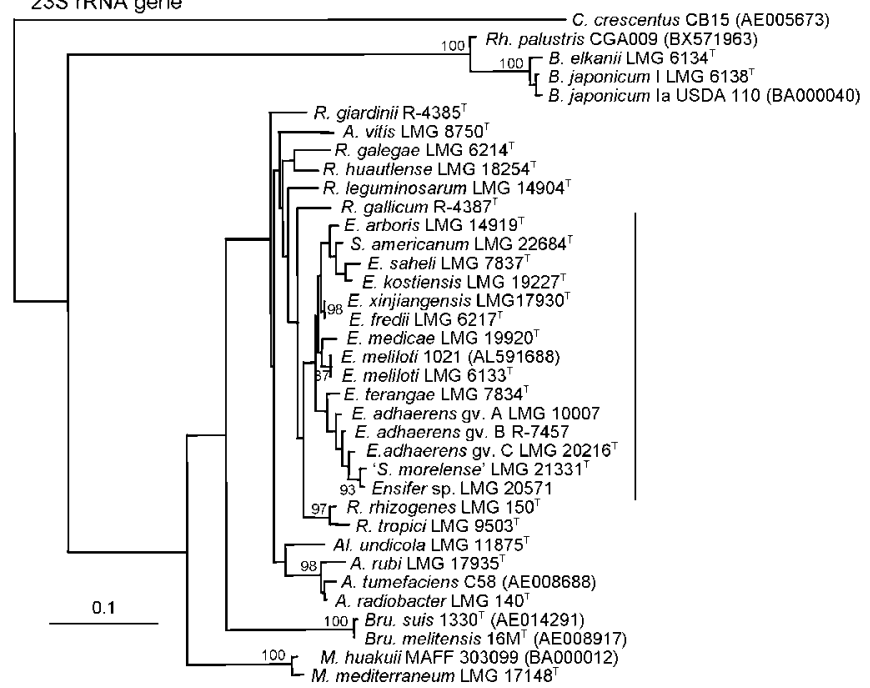

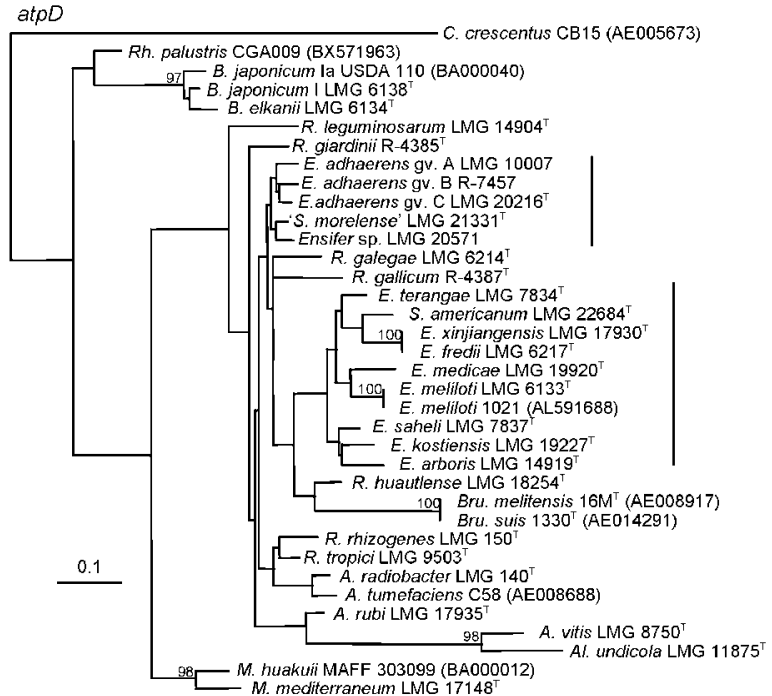

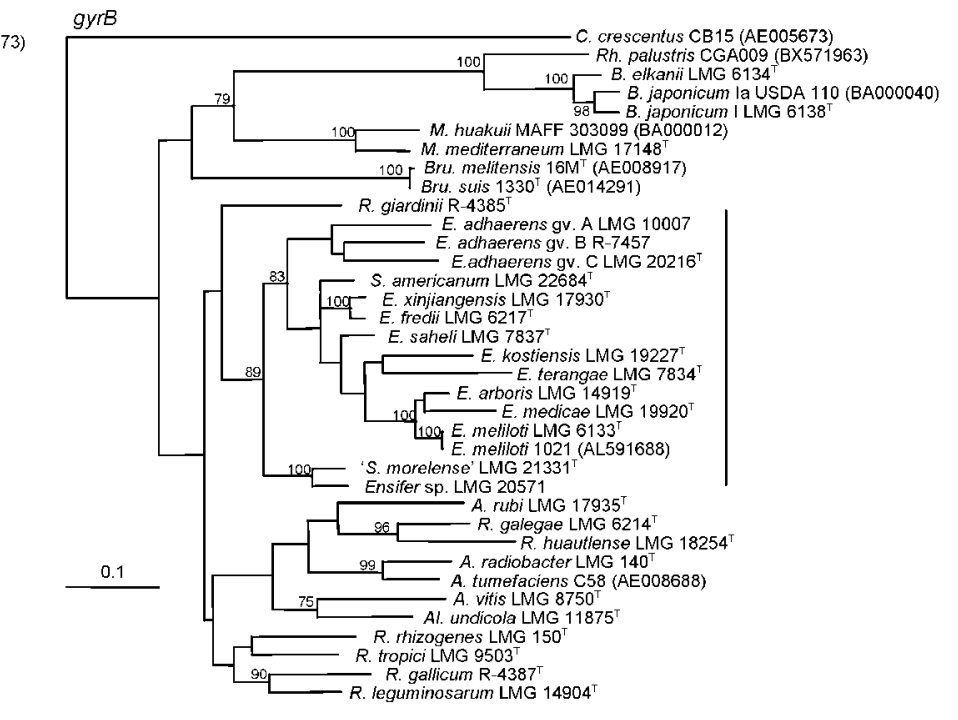

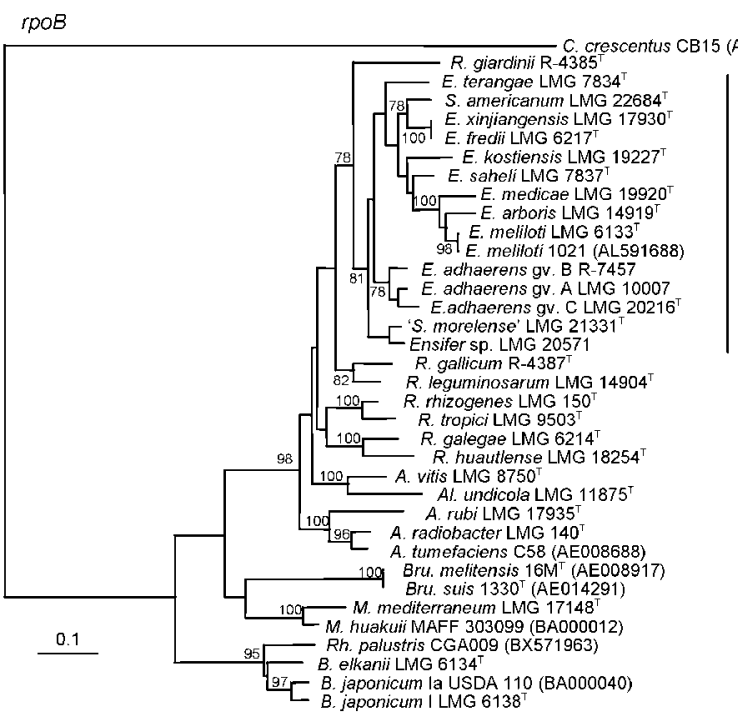
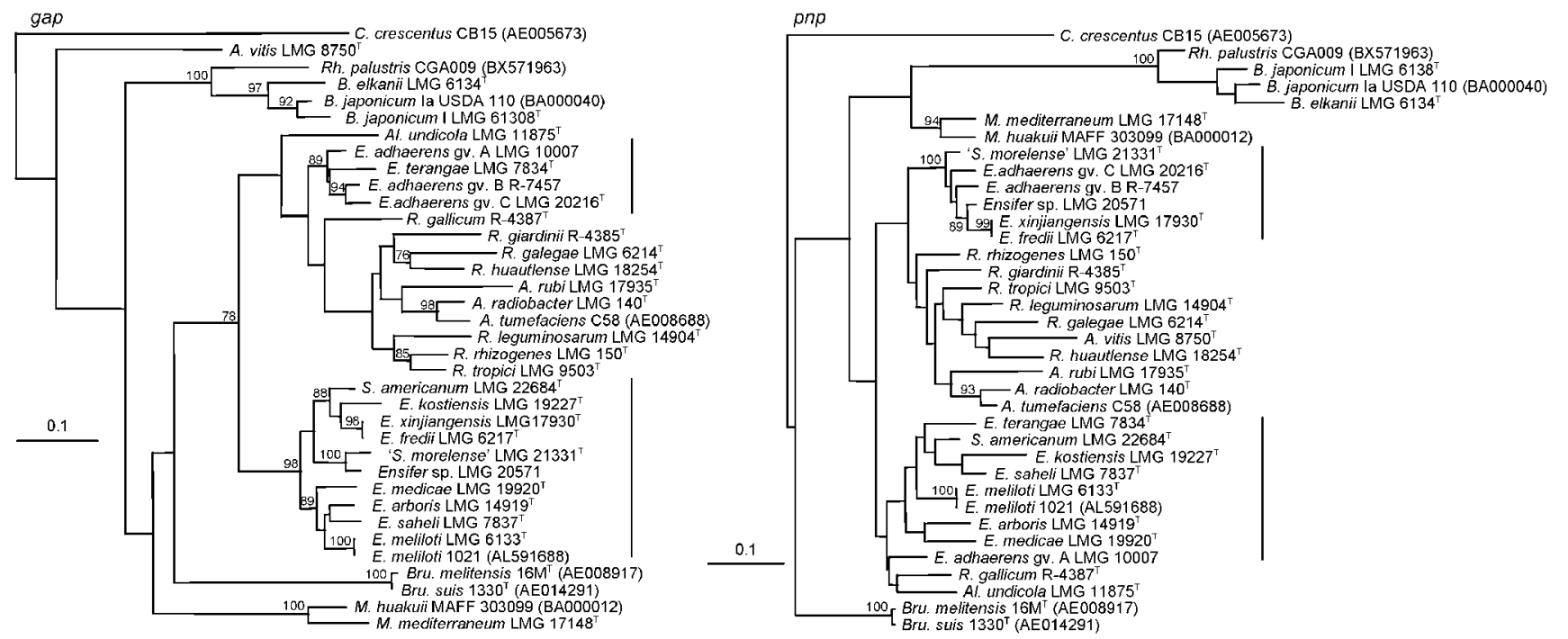
Fig. 2. Phylogenetic reconstructions based on individual analyses of the $23 \mathrm{~S} \mathrm{rRNA}$, atpD, rpoB, gyrB, gap and pnp genes. Analyses were conducted using the ML method. BT values of 75 or more (using 100 replicates) are indicated at branching points. Accession numbers for complete genome sequences are listed. Ensifer strains are marked by vertical bars. $A$., Agrobacterium; Al., Allorhizobium; B., Bradyrhizobium; Bru., Brucella; R., Rhizobium; Rh., Rhodopseudomonas. Bars, $0.1 \%$ estimated substitutions.

americanum (see also Fig. 1). In the $23 \mathrm{~S}$ rRNA gene analysis, the single cluster encompassing all Ensifer strains was also apparent, but was supported by only a very low BT value $(20 \%)$. For the $a t p D$, pnp and gap genes, aberrant groupings were found compared with other single-gene tree topologies from this and the previous study (Martens et al., 2007). In the atpD tree topology, the genus Ensifer was composed of two separate and poorly supported clusters: one cluster contained 'S. morelense' and the three genomovars of E. adhaerens (BT value $13 \%$ ), while the second cluster contained all other Ensifer species (BT value $50 \%)$. In the case of gap, Ensifer terangae and the different $E$. adhaerens genomovars clustered together with all Rhizobium and most Agrobacterium strains (BT value $55 \%)$, while all other Ensifer strains formed a single, separate clade (BT value $98 \%$ ). For pnp, the genus Ensifer was composed of two clusters: while one contained $E$. fredii, E. adhaerens gv. B and C, Ensifer sp. LMG 20571 and 'S. morelense' (BT value $100 \%$ ), the other, poorly supported cluster contained the remaining Ensifer strains, but also Allorhizobium undicola and Rhizobium gallicum (BT value $25 \%$ ). Thus atpD, gap and pnp resulted in trees in which other taxa were grouped between or within the Ensifer clusters. This different placement of species in individual gene tree analyses may be due to different evolutionary histories of the genes, intragenomic rearrangements or horizontal gene transfer and subsequent recombination events (Charles et al., 2005; Christensen et al., 2004; Rokas et al., 2003). Christensen \& Olsen (1998) previously reported conflicting results when comparing atpD with other housekeeping genes and the 23S rRNA gene in Salmonella.

\section{Composite tree}

The ILD test (Farris et al., 1995) was applied to assess congruence between the 12 genes. S. americanum LMG $22684^{\mathrm{T}}$, Agrobacterium vitis LMG $8750^{\mathrm{T}}$ and Allorhizobium undicola LMG $11875^{\mathrm{T}}$ were excluded from the comparison since no sequence was obtained for their $\operatorname{thr} C, g \ln A$ and gltA genes, respectively (Martens et al., 2007). E. medicae LMG 19921 was also excluded from the analyses since it exhibited an aberrant gyrB sequence which complicated gene sequence alignment considerably. Different levels of significant congruence were found between $d n a K, g \ln A$, gltA, gyrB, recA, rpoB and thrC (Supplementary Table S3). These seven congruent genes coincide with the subset of genes that produced the most consistent phylogenetic placement of species (with some minor incongruence within clades), except for the $d n a K$ gene, which exhibited a phylogeny with some aberrant clustering (Martens et al., 2007). The congruent gene sequence alignments were concatenated. In line with single-gene sequence characteristics (Fig. 1), heterogeneity values of the seven concatenated gene sequences were low (sequence divergence ranging from 0 to $2.7 \%$ ) within an Ensifer species/ genomovar, while sequence divergence was clearly higher at the interspecies/intergenomovar level (ranging from 5.5 to $14.2 \%$ ). The clear gap between intra- and interspecies sequence divergence values allows reliable identification of all species and results in clear species boundaries. Konstantinidis et al. (2006) demonstrated from a wholegenome comparison study in which the conserved core genes of several groups of organisms were analysed that the classical cut-off of $70 \%$ DNA-DNA hybridization for species delineation corresponds to $96 \%$ ANI. They also concluded that sequence similarity values of a concatenation of a random selection of six to eight genes should allow an accurate estimation of the total genome ANI value and give a significant prediction of whole-genome relatedness, even when the genes employed are among the worstperforming ones. This implies that similarity values from the concatenation of our housekeeping gene sequences may predict the total genome ANI values and, moreover, provide an easy tool to assess interorganismal relationships. In our study of seven concatenated genes, $2.7 \%$ sequence divergence at the intraspecies level was deduced as the species delineation level. This can be regarded as corresponding to an ANI value of $97.3 \%$. Inclusion of additional strains for each species and/or more variable housekeeping genes could provide an even better correlation with the $96 \%$ ANI value obtained by Konstantinidis et al. (2006).

A tree, including all examined Ensifer strains (except for $S$. americanum), was constructed for the concatenation of the seven congruent gene sequences applying the NJ, MP and ML methods. Regardless of which tree construction method was used, the same tree topology was obtained, and therefore only the ML tree is shown (Fig. 3). In line with most single-gene trees (Fig. 2), a close phylogenetic relationship was observed between E. meliloti, E. medicae and E. arboris (BT value $100 \%$ ) in the concatenated tree (Fig. 3). The combined analysis showed a cluster comprising all Ensifer strains, with two subclusters: one included ' $S$. morelense' and the three E. adhaerens genomovars, while the other subcluster included all other Ensifer strains. This is consistent with most single-gene trees, although the BT values are not always significant (Martens et al., 2007). However, in the concatenated tree, all mentioned clusters were supported by higher BT values than in the single-gene trees and were therefore more 
robust. In addition, we created a concatenated tree of all 12 gene sequences (10 housekeeping and two rRNA genes) (data not shown). Compared to the results from the concatenation of the congruent genes, a nearly identical tree with similarly high BT values was found. The inclusion of non-congruent genes in the concatenation thus has little impact on the resulting tree topology. This is in line with the observation of Wertz et al. (2003) that, as more sequences were concatenated, the influence of genes with an aberrant signal was reduced and the underlying common phylogenetic signal was reinforced, as demonstrated by the increase in BT values.

\section{Comparison of MLSA data with DNA-DNA reassociation data}

A limited number of studies have compared analyses of housekeeping genes with DNA-DNA hybridization data. Yamamoto et al. (1999) demonstrated that the phylogenetic clustering of Acinetobacter strains based on sequences of a single gene, $g y r B$, was almost equivalent to genomic species delineation by DNA-DNA hybridization. Nørskov-Lauritsen et al. (2005) used the phylogeny of four housekeeping genes to study Haemophilus. They found that these phylogenies confirmed DNA-DNA hybridization groupings, whereas 16S rRNA gene phylogeny does not in all cases. Stackebrandt et al. (2007) found discrepancies between four housekeeping gene phylogenies for Corallococcus strains. The 16S rRNA gene phylogeny was only partially recovered, although it was better reflected in a concatenated tree. DNADNA hybridizations showed a larger diversity than reflected in the 16S rRNA gene phylogeny, but a clear comparison between housekeeping gene analyses and hybridization data was not made.

To evaluate the resolution of our MLSA data for taxonomic purposes, we compared them with a compilation of reported and new DNA-DNA hybridization results. Table 2 represents the DNA-DNA hybridization values available for Ensifer strains included in this study (de Lajudie et al., 1994; Nick et al., 1999; Peng et al., 2002; Toledo et al., 2003; Wang et al., 2002; Willems et al., 2003). Strains sharing over $70 \%$ overall genome relatedness, and thus representing a single species, are grouped together.

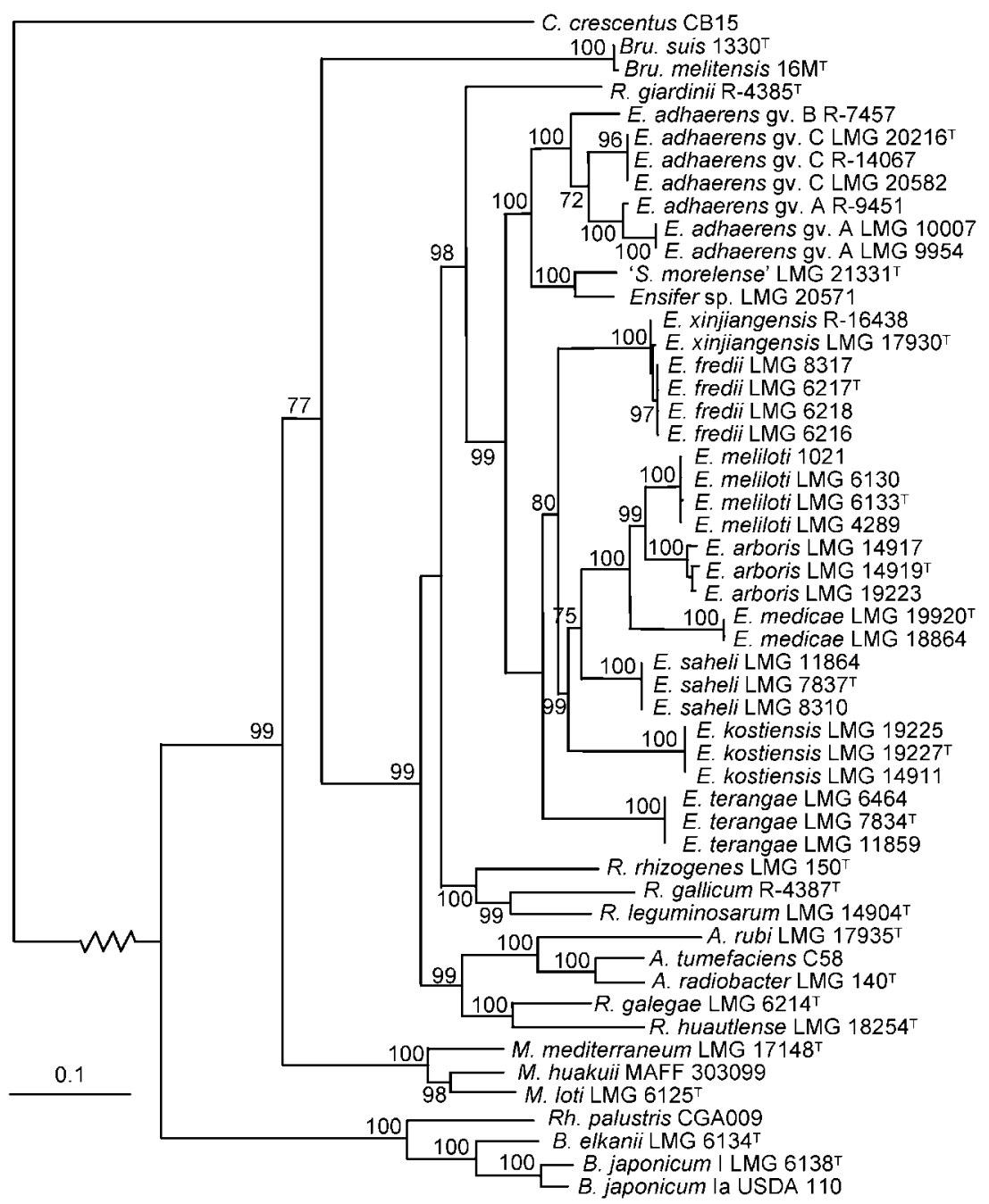

Fig. 3. Phylogenetic reconstruction based on the concatenated $r e c A, r p o B, g y r B$, dnaK, $g \ln A, g / t A$ and $t h r C$ gene sequences. Analyses were conducted using the $\mathrm{ML}$ method. BT values of 70 or more (using 100 replicates) are indicated at branching points. Bar, $0.1 \%$ estimated substitutions. 
The three E. adhaerens genomovars are related groups within E. adhaerens (DNA-DNA reassociation values between 50 and $70 \%$ ), distinguishable by genotypic but not by phenotypic tests (Willems et al., 2003).

The linear Pearson's product-moment correlation coefficient was employed to permit a comparison of DNADNA reassociation data with our gene sequencing results (Supplementary Fig. S1). Product-moment $(r)$ values were calculated between the DNA-DNA relatedness matrix and the corresponding similarity matrices of the respective gene sequences from $t h r C, d n a K, g y r B, r p o B, g \ln A, g l t A$ and $r e c A$, a concatenation of these congruent genes and the $16 \mathrm{~S}$ rRNA gene. Regression analysis showed a highly significant correlation between DNA-DNA hybridization values and sequence similarity values of the housekeeping genes, $(r$ values ranging from 0.88 for $g y r B$ to 0.93 for the seven concatenated genes). Correlation between DNA-DNA reassociation values and the $16 \mathrm{~S}$ rRNA gene was lower $(r=0.78)$. 16S rRNA gene sequence analysis can only reliably depict relationships to the species level for moderately related strains (below 97\% similarity) (Stackebrandt \& Goebel, 1994). For example, 16S rRNA gene sequence similarities of Ensifer species may be as high as $100 \%$ at DNA-DNA hybridization levels of $31 \%$ ( $S$. americanum LMG $22684^{\mathrm{T}}$ and E. fredii $\mathrm{LMG} 6217^{\mathrm{T}}$ ). Correlation between similarity values for the 16S rRNA gene and the seven concatenated genes was also lower $(r=0.78)$. The highest correlation $(r=0.93)$ was found between DNA-DNA hybridization values and similarity values for the seven concatenated genes, which also supports the conclusion of Konstantinidis et al. (2006) that a concatenation of genes gives an accurate prediction of interorganismal relationships. The taxonomic resolution of housekeeping gene sequencing equals that of DNADNA hybridization; MLSA provides reliable information to the subspecies level. Indeed, at the intraspecies/genomovar level, relationships suggested by MLSA data (Fig. 3) corresponded with those revealed by DNA-DNA hybridization. For example, E. adhaerens gv. A strains LMG 9954 and LMG 10007 display $100 \%$ sequence similarity (seven concatenated gene sequences) and shared $96 \%$ DNA-DNA relatedness (mean value). Strains LMG 9954 and LMG 10007 displayed somewhat lower sequence similarity values with R-9451 (97.3\% similarity with both strains), corresponding with the slightly lower DNA-DNA hybridization values (mean values of 85 and $90 \%$ respectively). At the interspecies/genomovar level, interorganismal relationships for highly related strains (sharing 50-70\% DNA-DNA relatedness) are more obvious from MLSA data. For example, E. adhaerens gv. A LMG 10007 and E. adhaerens gv. B R-7457 share $93.3 \%$ sequence similarity for the concatenated gene sequences (compared with the cut-off value of $97.3 \%$ for species level delineation; a clear gap is observed), while displaying a DNA-DNA relatedness of $67 \%$ (cut-off value of $70 \%$ for species-level delineation). A close relationship between the E. adhaerens genomovars is shown by both methods, but differentiation of the genomovars (distinction of the genomic species) is more clear from the MLSA data. In Supplementary Fig. S1, the gap between housekeeping gene sequence similarity values within and between species, i.e. the species boundary, is clear. From the DNA-DNA hybridization values, this gap between reassociation values within a species $(\geqslant 70 \%$ relative DNA relatedness) and between species $(<70 \%$ relative DNA relatedness) is not clear at all. Goris et al. (2007) already noted that the $70 \%$ relatedness rule for species delineation is rather arbitrary, since their DNADNA hybridization data show a continuous gradient of overall genetic relatedness rather than discrete species boundaries. For less closely related Ensifer strains $(<50 \%$ DNA-DNA relatedness), no information on particular interspecies/genomovar relationships is apparent from DNA-DNA hybridization. In contrast, our analyses of single and concatenated genes (seven or twelve) indicate some particular associations. For example, close relationships were observed between $S$. americanum and $E$. fredii (and E. xinjiangensis), between 'S. morelense' and the three E. adhaerens genomovars and between E. meliloti, E. medicae and E. arboris (Figs 1, 2 and 3). These close relationships are not apparent from DNA-DNA reassociation levels (Table 2).

Since sequence similarity values and tree topologies (Figs 1 , 2 and 3) were congruent with the genomic species previously delineated on the basis of DNA-DNA hybridization studies, our study indicates that even the single housekeeping gene analyses provide a robust species delineation that is at least equivalent and even superior to DNA-DNA hybridization (Supplementary Fig. S1). Delineating strains into species, based solely on the MLSA data and without prior knowledge of their classification, would result in the same genomic species. MLSA, like DNA-DNA hybridization, is a suitable technique for species delineation and for assessing relationships at the intraspecies level. MLSA surpasses DNA-DNA hybridization by its ability to give information on interspecies relationships and by providing clear species/ genomovar boundaries.

Comparison of the MLSA data from our set of strains with DNA profiling methods such as rep-PCR and wholegenome dot-blot hybridization (Nick et al., 1999) indicates clusters of the same genomic species. However, intraspecific genomic variation is more pronounced for the fingerprint techniques that cover a larger part of the genome. A selection of more strains per species and more variable genes to study intraspecific diversity, entering the field of multilocus sequence typing (MLST) (Maiden et al., 1998), should provide higher variability within species and even better correlation with genomic methods. Since whole-genome methods such as rep-PCR take into account plasmids and non-essential genes and DNA, they can reveal strains that are intermediate between species that were delineated based on a selected set of significant characteristics. Because MLSA targets housekeeping genes, we would expect fewer intermediate strains and more clear-cut groupings. 
Table 2. DNA relatedness between Ensifer strains assessed by DNA-DNA hybridization

Results taken from other studies are indicated as follows: $a$, Willems et al. (2003) (values obtained using a microplate hybridization method); $b$, Toledo et al. (2003) (microplate hybridization); c, Nick et al. (1999) (spectrophotometric); d, Peng et al. (2002) (spectrophotometric); $e$, Wang et al. (2002) (Southern hybridization of total DNA); f, de Lajudie et al. (1994) (spectrophotometric); $g$, Wang et al. (2002) (microplate hybridization).

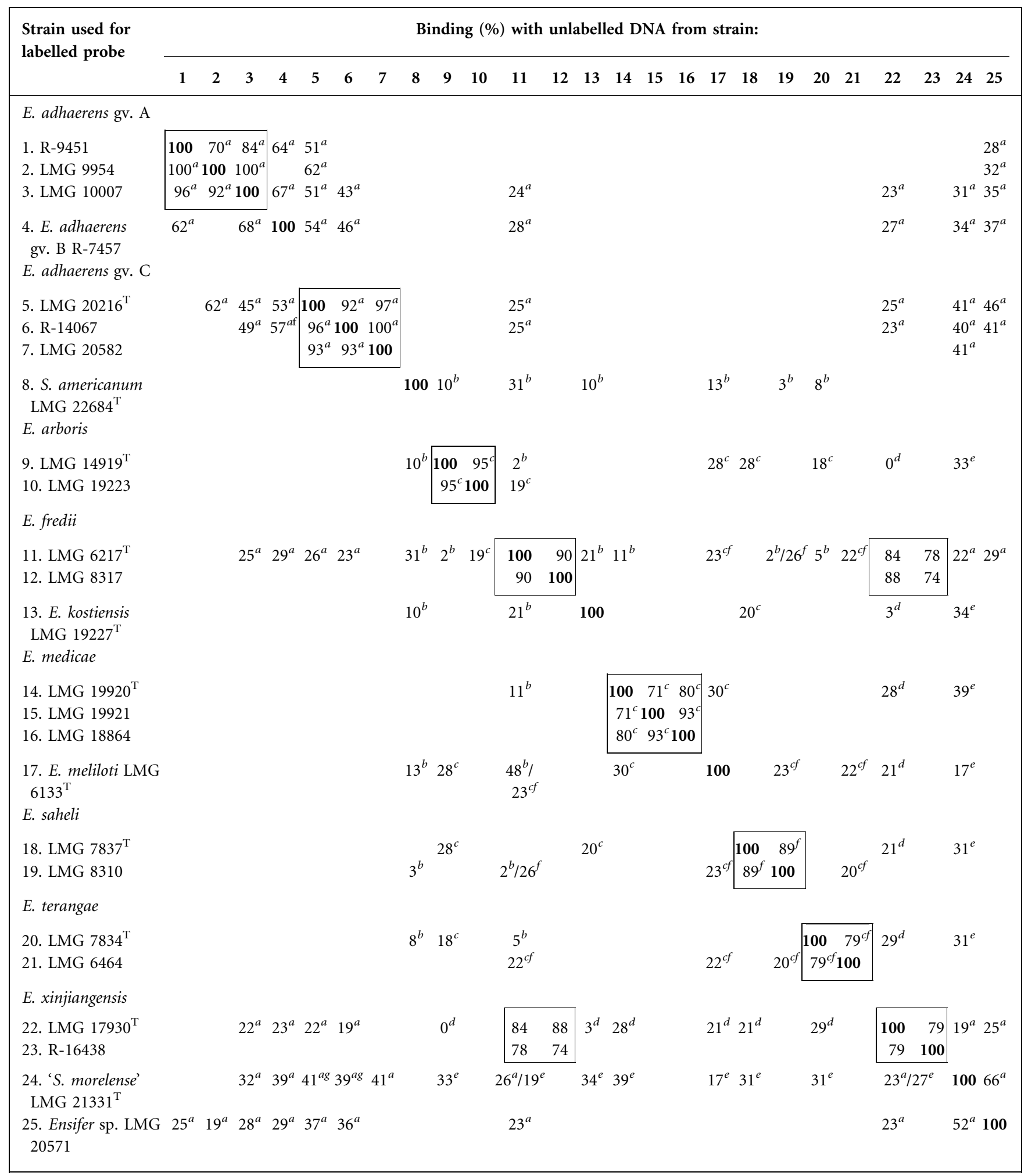


In conclusion, MLSA offers a very good, reliable alternative to DNA-DNA hybridization for the study of genomic relationships between bacteria from a particular group. It has the important advantage of yielding cumulative, exact data which, through database query, can be compared with sequence data from unknown organisms. MLSA of selected housekeeping genes, although not a genome-wide comparison technique, accurately predicts relationships between closely related organisms. It has great potential for species delineation and identification and for studying bacterial relationships at a wide range of evolutionary distances, from the intraspecies level to at least the genus level. For identification purposes, it seems prudent to study at least two independent housekeeping genes, since lateral gene transfer instances in a particular gene can not be excluded. A general identification strategy for new isolates could consist of initial partial sequencing of the 16S rRNA gene for genus-level identification. This remains valuable because of the large and comprehensive database available. This information can then guide the selection of suitable housekeeping genes (as a function of available reference data) for species identification. For phylogenetic analyses, more housekeeping genes should be analysed than for identification purposes. Incongruent phylogenies indicate possible horizontal transfer, whereas congruent phylogenies reflect the common history of genes. In the case of rhizobia, housekeeping genes with good capability to identify and classify strains are the gyrB, gltA, recA and thrC genes.

\section{ACKNOWLEDGEMENTS}

This work was performed in the framework of project QLK3-CT2002-02097 funded by the Commission of the European Communities and project G.0156.02 funded by the Fund for Scientific Research - Flanders. A.W. is grateful for a post-doctoral fellowship of the Fund for Scientific Research - Flanders. We thank Manuel Delaere for his contribution to the phylogenetic analyses.

\section{REFERENCES}

Acinas, S. G., Marcelino, L. A., Klepac-Ceraj, V. \& Polz, M. F. (2004). Divergence and redundancy of $16 \mathrm{~S}$ rRNA sequences in genomes with multiple rrn operons. J Bacteriol 186, 2629-2635.

Adekambi, T. \& Drancourt, M. (2004). Dissection of phylogenetic relationships among 19 rapidly growing Mycobacterium species by $16 \mathrm{~S}$ rRNA, hsp65, sodA, recA and rpoB gene sequencing. Int J Syst Evol Microbiol 54, 2095-2105.

Altschul, S. F., Madden, T. L., Schaffer, A. A., Zhang, J., Zhang, Z., Miller, W. \& Lipman, D. J. (1997). Gapped BLAST and PSI-BLAST: a new generation of protein database search programs. Nucleic Acids Res 25, 3389-3402.

Amann, R. I., Lin, C. H., Key, R., Montgomery, L. \& Stahl, D. A. (1992). Diversity among Fibrobacter strains: towards a phylogenetic classification. Syst Appl Microbiol 15, 23-32.

Baele, M., Baele, P., Vaneechoutte, M., Storms, V., Butaye, P., Devriese, L. A., Verschraegen, G., Gillis, M. \& Haesebrouck, F. (2000). Application of tRNA intergenic spacer PCR for identification of Enterococcus species. J Clin Microbiol 38, 4201-4207.
Charles, L., Carbone, I., Davies, K. G., Bird, D., Burke, M., Kerry, B. R. \& Opperman, C. H. (2005). Phylogenetic analysis of Pasteuria penetrans by use of multiple genetic loci. J Bacteriol 187, 5700-5708.

Cho, J. C. \& Tiedje, J. M. (2001). Bacterial species determination from DNA-DNA hybridization by using genome fragments and DNA microarrays. Appl Environ Microbiol 67, 3677-3682.

Christensen, H. \& Olsen, J. E. (1998). Phylogenetic relationships of Salmonella based on DNA sequence comparison of atpD encoding the beta subunit of ATP synthase. FEMS Microbiol Lett 161, 89-96.

Christensen, H., Kuhnert, P., Olsen, J. E. \& Bisgaard, M. (2004). Comparative phylogenies of the housekeeping genes atpD, infB and $r p o B$ and the 16S rRNA gene within the Pasteurellaceae. Int J Syst Evol Microbiol 54, 1601-1609.

Coenye, T., Gevers, D., Van de Peer, Y., Vandamme, P. \& Swings, J. (2005). Towards a prokaryotic genomic taxonomy. FEMS Microbiol Rev 29, 147-167.

de Lajudie, P., Willems, A., Pot, B., Dewettinck, D., Maestrojuan, G., Neyra, M., Collins, M. D., Dreyfus, B., Kersters, K. \& Gillis, M. (1994). Polyphasic taxonomy of rhizobia - emendation of the genus Sinorhizobium and description of Sinorhizobium meliloti comb. nov., Sinorhizobium saheli sp. nov. and Sinorhizobium terangae sp. nov. Int J Syst Bacteriol 44, 715-733.

DelVecchio, V. G., Kapatral, V., Redkar, R. J., Patra, G., Mujer, C., Los, T., Ivanova, N., Anderson, I., Bhattacharyya, A. \& other authors (2002). The genome sequence of the facultative intracellular pathogen Brucella melitensis. Proc Natl Acad Sci U S A 99, 443-448.

Euzéby, J. P. \& Tindall, B. J. (2004). Status of strains that contravene Rules 27(3) and 30 of the Bacteriological Code. Request for an Opinion. Int J Syst Evol Microbiol 54, 293-301.

Ezaki, T., Hashimoto, Y. \& Yabuuchi, E. (1989). Fluorometric deoxyribonucleic acid-deoxyribonucleic acid hybridization in microdilution wells as an alternative to membrane filter hybridization in which radioisotopes are used to determine genetic relatedness among bacterial strains. Int J Syst Bacteriol 39, 224-229.

Farris, J. S., Kallersjo, M., Kluge, A. G. \& Bult, C. (1995). Constructing a significance test for incongruence. Syst Biol 44, 570-572.

Fox, G. E., Wisotzkey, J. D. \& Jurtshuk, P., Jr (1992). How close is close: $16 \mathrm{~S}$ ribosomal RNA sequence identity may not be sufficient to guarantee species identity. Int J Syst Bacteriol 42, 166-170.

Galibert, F., Finan, T. M., Long, S. R., Puhler, A., Abola, P., Ampe, F., Barloy-Hubler, F., Barnett, M. J., Becker, A. \& other authors (2001). The composite genome of the legume symbiont Sinorhizobium meliloti. Science 293, 668-672.

Gevers, D., Cohan, F. M., Lawrence, J. G., Spratt, B. G., Coenye, T., Feil, E. J., Stackebrandt, E., Van de Peer, Y., Vandamme, P. \& other authors (2005). Re-evaluating prokaryotic species. Nat Rev Microbiol 3, 733-739.

Goodfellow, M., Manfio, G. P. \& Chun, J. (1997). Towards a practical species concept for cultivable bacteria. In Species: the Units of Biodiversity, pp. 25-59. Edited by M. F. Claridge \& H. A. Dawah. London: Chapman \& Hall.

Goodner, B., Hinkle, G., Gattung, S., Miller, N., Blanchard, M., Qurollo, B., Goldman, B. S., Cao, Y., Askenazi, M. \& other authors (2001). Genome sequence of the plant pathogen and biotechnology agent Agrobacterium tumefaciens C58. Science 294, 2323-2328.

Goris, J., Konstantinidis, K. T., Klappenbach, J. A., Coenye, T., Vandamme, P. \& Tiedje, J. M. (2007). DNA-DNA hybridization values and their relationship to whole-genome sequence similarities. Int J Syst Evol Microbiol 57, 81-91.

Holmes, D. E., Nevin, K. P. \& Lovley, D. R. (2004). Comparison of $16 \mathrm{~S}$ rRNA, nifD, recA, gyrB, rpoB and fusA genes within the family Geobacteraceae fam. nov. Int J Syst Evol Microbiol 54, 1591-1599. 
Jaspers, E. \& Overmann, J. (2004). Ecological significance of microdiversity: identical $16 \mathrm{~S}$ rRNA gene sequences can be found in bacteria with highly divergent genomes and ecophysiologies. Appl Environ Microbiol 70, 4831-4839.

Kaneko, T., Nakamura, Y., Sato, S., Asamizu, E., Kato, T., Sasamoto, S., Watanabe, A., Idesawa, K., Ishikawa, K. \& other authors (2000). Complete genome structure of the nitrogen-fixing symbiotic bacterium Mesorhizobium loti. DNA Res 7, 331-338.

Kaneko, T., Nakamura, Y., Sato, S., Minamisawa, K., Uchiumi, T., Sasamoto, S., Watanabe, A., Idesawa, K., Iriguchi, M. \& other authors (2002). Complete genomic sequence of nitrogen-fixing symbiotic bacterium Bradyrhizobium japonicum USDA110. DNA Res 9, 189-197.

Konstantinidis, K. T. \& Tiedje, J. M. (2005). Genomic insights that advance the species definition for prokaryotes. Proc Natl Acad Sci U S A 102, 2567-2572.

Konstantinidis, K. T., Ramette, A. \& Tiedje, J. M. (2006). Toward a more robust assessment of intraspecies diversity, using fewer genetic markers. Appl Environ Microbiol 72, 7286-7293.

Kwon, S. W., Park, J. Y., Kim, J. S., Kang, J. W., Cho, Y. H., Lim, C. K., Parker, M. A. \& Lee, G. B. (2005). Phylogenetic analysis of the genera Bradyrhizobium, Mesorhizobium, Rhizobium and Sinorhizobium on the basis of $16 \mathrm{~S}$ rRNA gene and internally transcribed spacer region sequences. Int J Syst Evol Microbiol 55, 263-270.

Larimer, F. W., Chain, P., Hauser, L., Lamerdin, J., Malfatti, S., Do, L., Land, M. L., Pelletier, D. A., Beatty, J. T. \& other authors (2004). Complete genome sequence of the metabolically versatile photosynthetic bacterium Rhodopseudomonas palustris. Nat Biotechnol 22, 55-61.

Maiden, M. C. J., Bygraves, J. A., Feil, E., Morelli, G., Russell, J. E., Urwin, R., Zhang, Q., Zhou, J. J., Zurth, K. \& other authors (1998). Multilocus sequence typing: a portable approach to the identification of clones within populations of pathogenic microorganisms. Proc Natl Acad Sci U S A 95, 3140-3145.

Marmur, J. (1961). A procedure for the isolation of deoxyribonucleic acid from microorganisms. J Mol Biol 3, 208-218.

Martens, M., Delaere, M., Coopman, R., De Vos, P., Gillis, M. \& Willems, A. (2007). Multilocus sequence analysis of Ensifer and related taxa. Int J Syst Evol Microbiol 57, 489-503.

Mollet, C., Drancourt, M. \& Raoult, D. (1997). $r p o B$ sequence analysis as a novel basis for bacterial identification. Mol Microbiol 26, $1005-1011$.

Naser, S. M., Thompson, F. L., Hoste, B., Gevers, D., Dawyndt, P., Vancanneyt, M. \& Swings, J. (2005). Application of multilocus sequence analysis (MLSA) for rapid identification of Enterococcus species based on rpoA and pheS genes. Microbiology 151, 2141-2150.

Naser, S. M., Dawyndt, P., Hoste, B., Gevers, D., Vandemeulebroecke, K., Cleenwerck, I., Vancanneyt, M. \& Swings, J. (2007). Identification of lactobacilli by pheS and rpoA gene sequence analyses. Int J Syst Evol Microbiol 57, 2777-2789.

Nick, G., Jussila, M., Hoste, B., Niemi, R. M., Kaijalainen, S., de Lajudie, P., Gillis, M., de Bruijn, F. J. \& Lindström, K. (1999). Rhizobia isolated from root nodules of tropical leguminous trees characterized using DNA-DNA dot-blot hybridisation and rep-PCR genomic fingerprinting. Syst Appl Microbiol 22, 287-299.

Nierman, W. C., Feldblyum, T. V., Laub, M. T., Paulsen, I. T., Nelson, K. E., Eisen, J., Heidelberg, J. F., Alley, M. R. K., Ohta, N. \& other authors (2001). Complete genome sequence of Caulobacter crescentus. Proc Natl Acad Sci U S A 98, 4136-4141.

Nørskov-Lauritsen, N., Bruun, B. \& Kilian, M. (2005). Multilocus sequence phylogenetic study of the genus Haemophilus with description of Haemophilus pittmaniae sp. nov. Int J Syst Evol Microbiol 55, 449-456.
Owen, R. J. \& Pitcher, D. (1983). Current methods for determining DNA-base composition and levels of DNA-DNA hybridization. J Appl Bacteriol 55, R16-R16.

Paulsen, I. T., Seshadri, R., Nelson, K. E., Eisen, J. A., Heidelberg, J. F., Read, T. D., Dodson, R. J., Umayam, L., Brinkac, L. M. \& other authors (2002). The Brucella suis genome reveals fundamental similarities between animal and plant pathogens and symbionts. Proc Natl Acad Sci U S A 99, 13148-13153.

Peng, G. X., Tan, Z. Y., Wang, E. T., Reinhold-Hurek, B., Chen, W. F. \& Chen, W. X. (2002). Identification of isolates from soybean nodules in Xinjiang Region as Sinorhizobium xinjiangense and genetic differentiation of S. xinjiangense from Sinorhizobium fredii. Int J Syst Evol Microbiol 52, 457-462.

Posada, D. \& Buckley, T. R. (2004). Model selection and model averaging in phylogenetics: advantages of Akaike information criterion and Bayesian approaches over likelihood ratio tests. Syst Biol 53, 793-808.

Posada, D. \& Crandall, K. A. (1998). MODELTEST: testing the model of DNA substitution. Bioinformatics 14, 817-818.

Rokas, A., King, N., Finnerty, J. \& Carroll, S. B. (2003). Conflicting phylogenetic signals at the base of the metazoan tree. Evol Dev 5, 346-359.

Rönner, S., Liesack, W., Wolters, J. \& Stackebrandt, E. (1991). Cloning and sequencing of a large fragment of the atpD gene of Pirellula marina - a contribution to the phylogeny of Planctomycetales. Endocytobiosis Cell Res 7, 219-229.

Rosselló-Mora, R. (2006). DNA-DNA reassociation methods applied to microbial taxonomy and their critical evaluation. In Molecular Identification, Systematics, and Population Structure of Prokaryotes, pp. 23-50. Edited by E. Stackebrandt. Heidelberg: Springer.

Selenska-Pobell, S. \& Evguenieva-Hackenberg, E. (1995). Fragmentations of the large-subunit rRNA in the family Rhizobiaceae. J Bacteriol 177, 6993-6998.

Stackebrandt, E. \& Goebel, B. M. (1994). Taxonomic note: a place for DNA-DNA reassociation and $16 S$ rRNA sequence analysis in the present species definition in bacteriology. Int J Syst Bacteriol 44, 846-849.

Stackebrandt, E., Frederiksen, W., Garrity, G. M., Grimont, P. A., Kämpfer, P., Maiden, M. C. J., Nesme, X., Rosselló-Mora, R., Swings, J. \& other authors (2002). Report of the ad hoc committee for the reevaluation of the species definition in bacteriology. Int J Syst Evol Microbiol 52, 1043-1047.

Stackebrandt, E., Päuker, O., Steiner, U., Schumann, P., Sträubler, B., Heibei, S. \& Lang, E. (2007). Taxonomic characterization of members of the genus Corallococcus: molecular divergence versus phenotypic coherency. Syst Appl Microbiol 30, 109-118.

Sullivan, J. T., Eardly, B. D., van Berkum, P. \& Ronson, C. W. (1996). Four unnamed species of nonsymbiotic rhizobia isolated from the rhizosphere of Lotus corniculatus. Appl Environ Microbiol 62, 2818-2825.

Swofford, D. L. (2002). PAUP*: phylogenetic analysis using parsimony (and other methods), version 4. Sunderland, MA: Sinauer Associates.

Tan, Z. Y., Xu, X. D., Wang, E. T., Gag, J. L., Martínez-Romero, E. \& Chen, W. X. (1997). Phylogenetic and genetic relationships of Mesorhizobium tianshanense and related rhizobia. Int J Syst Bacteriol 47, 874-879.

Thompson, J. D., Gibson, T. J., Plewniak, F., Jeanmougin, F. \& Higgins, D. G. (1997). The CLUSTAL_X windows interface: flexible strategies for multiple sequence alignment aided by quality analysis tools. Nucleic Acids Res 25, 4876-4882.

Thompson, F. L., Gevers, D., Thompson, C. C., Dawyndt, P., Naser, S., Hoste, B., Munn, C. B. \& Swings, J. (2005). Phylogeny and molecular 
identification of vibrios on the basis of multilocus sequence analysis. Appl Environ Microbiol 71, 5107-5115.

Toledo, I., Lloret, L. \& Martínez-Romero, E. (2003). Sinorhizobium americanum sp. nov., a new Sinorhizobium species nodulating native Acacia spp. in Mexico. Syst Appl Microbiol 26, 54-64.

Turner, S. L., Zhang, X.-X., Li, F.-D. \& Young, J. P. W. (2002). What does a bacterial genome sequence represent? Mis-assignment of MAFF 303099 to the genospecies Mesorhizobium loti. Microbiology 148, 3330-3331.

Van Camp, G., Chapelle, S. \& De Wachter, R. (1993). Amplification and sequencing of variable regions in bacterial $23 \mathrm{~S}$ ribosomal RNA genes with conserved primer sequences. Curr Microbiol 27, 147-151.

Wang, E. T., Tan, Z. Y., Willems, A., Fernández-López, M., ReinholdHurek, B. \& Martínez-Romero, E. (2002). Sinorhizobium morelense sp nov., a Leucaena leucocephala-associated bacterium that is highly resistant to multiple antibiotics. Int J Syst Evol Microbiol 52, 1687-1693.

Wayne, L. G., Brenner, D. J., Colwell, R. R., Grimont, P. A. D., Kandler, O., Krichevsky, M. I., Moore, L. H., Moore, W. E. C., Murray, R. G. E. \& other authors (1987). International Committee on Systematic Bacteriology. Report of the ad hoc committee on reconciliation of approaches to bacterial systematics. Int J Syst Bacteriol 37, 463-464.

Wernersson, R. \& Pedersen, A. G. (2003). RevTrans: multiple alignment of coding DNA from aligned amino acid sequences. Nucleic Acids Res 31, 3537-3539.

Wertz, J. E., Goldstone, C., Gordon, D. M. \& Riley, M. A. (2003). A molecular phylogeny of enteric bacteria and implications for a bacterial species concept. J Evol Biol 16, 1236-1248.

Willems, A., Doignon-Bourcier, F., Goris, J., Coopman, R., de Lajudie, P., De Vos, P. \& Gillis, M. (2001). DNA-DNA hybridization study of Bradyrhizobium strains. Int J Syst Evol Microbiol 51, 1315-1322.

Willems, A., Fernández-López, M., Muñoz-Adelantado, E., Goris, J., De Vos, P., Martínez-Romero, E., Toro, N. \& Gillis, M. (2003). Description of new Ensifer strains from nodules and proposal to transfer Ensifer adhaerens Casida 1982 to Sinorhizobium as Sinorhizobium adhaerens comb. nov. Request for an Opinion. Int $J$ Syst Evol Microbiol 53, 1207-1217.

Woese, C. R. (1987). Bacterial evolution. Microbiol Rev 51, 221-271.

Wood, D. W., Setubal, J. C., Kaul, R., Monks, D. E., Kitajima, J. P., Okura, V. K., Zhou, Y., Chen, L., Wood, G. E. \& other authors (2001). The genome of the natural genetic engineer Agrobacterium tumefaciens C58. Science 294, 2317-2323.

Yamamoto, S. \& Harayama, S. (1995). PCR amplification and direct sequencing of $g y r B$ genes with universal primers and their application to the detection and taxonomic analysis of Pseudomonas putida strains. Appl Environ Microbiol 61, 1104-1109.

Yamamoto, S., Bouvet, P. J. M. \& Harayama, S. (1999). Phylogenetic structures of the genus Acinetobacter based on $\operatorname{gyr} B$ sequences: comparison with the grouping by DNA-DNA hybridization. Int J Syst Bacteriol 49, 87-95.

Young, J. M. (2003). The genus name Ensifer Casida 1982 takes priority over Sinorhizobium Chen et al. 1988, and Sinorhizobium morelense Wang et al. 2002 is a later synonym of Ensifer adhaerens Casida 1982. Is the combination 'Sinorhizobium adhaerens' (Casida 1982) Willems et al. 2003 legitimate? Request for an Opinion. Int J Syst Evol Microbiol 53, 2107-2110.

Zeigler, D. R. (2003). Gene sequences useful for predicting relatedness of whole genomes in bacteria. Int J Syst Evol Microbiol 53, 1893-1900. 